Sizewell inquiry

\section{Funds for objectors growing well}

FUND-RAISING appears to be going well for objectors to the plans of the Central Electricity Generating Board (CEGB) for Britain's first pressurized water reactor at Sizewell, Suffolk, despite the departure from the stage last week of the Sizewell B Appeal Fund (see Nature 24 March, p.282).

The fund closed with a total of $£ 4,000$ after approaches to industrial companies failed to attract support. Professor Sir Hans Kornberg, one of the fund's trustees, said he thought the fund had perhaps been too broad in its appeal, as most committed individuals would probably be supporting one or other of the main objectors directly. Among the major organizations being represented at the inquiry now being held at Snape in Suffolk, the Council for the Preservation of Rural England (CPRE) has already raised its initial target figure of $£ 46,000$ and is hoping to reach the $£ 60,000$ it now thinks will be needed. Friends of the Earth's "Sizewell Fighting Fund" has raised more than half its goal of $£ 100,000$ and the Town and Country Planning Association is well on the way to a target of around $£ 50,000$. The Stop Sizewell B Association, hopes to raise about $£ 30,000$.

Several county councils are also spending substantial sums on the inquiry. Northumberland County Council is

estimated to have spent $£ 100,000$. The Labour-controlled Greater London Council (GLC) is understood to have spent $£ 50,000$ on research for its presentation at the inquiry and is spending an additional $£ 50,000$ on publicity and conferences to air nuclear issues. Chief among these is the international conference on the urban transportation of irradiated fuel, which takes place in London this week.

The conference, organized by Technica, an independent firm of consulting scientists and engineers. attracted some influential participants, including $\mathrm{Mr}$ Christopher Audland, director general of energy at the EEC Commission, Mr Morris Rosen of the International Atomic Energy Authority and Mr Roger Clark of the UK National Radiological Protection Board. CEGB has, however, declined to send a representative: a board spokesman said GLC was already in possession of all available information on CEGB's fuel transport plans, and that CEGB felt it would be inappropriate to appear at a conference which was "clearly not impartial". Ms Patricia King-Smith, one of the conference organizers, says, however, that all shades of opinion are being represented, as GLC asked for an "unbiased conference".

Tim Beardsley

\section{Tasmanian dam}

\section{State and government conflict}

\section{Canberra}

A REGULATION published by the federal government making work on the Gordonbelow-Franklin Dam in Tasmania illegal has precipitated an impending battle between state and federal governments in the high court. Drafted after the Tasmanian Premier, Mr Robin Gray, appeared deaf to two entreaties for a moratorium on work while a settlement was negotiated, the World Heritage (Western Tasmania Wilderness) Regulation states: "Except with the consent of the Minister (for Environment), a person (including Tasmania) shall not . . . construct a dam or associated works". Although offenders may be liable to be fined $\$ A 5,000$, enforcing the regulations presents formidable difficulties.

An intransigent Mr Gray, who has consistently turned down offers of compensation, has forced the federal government's hand. Apparently the non-negotiable bottom line that the dam must be stopped is unacceptable to Tasmania. As a consequence, both parties scurried to the high court on 6 April to seek injunctions - $\mathrm{Mr}$ Bob Hawke (Prime Minister of Australia) to enforce the regulations until the case can be heard and Mr Gray to challenge the validity of the new regulations. Nevertheless, since the regulations came into force just before Easter, work has continued only outside the boundaries of the World Heritage site. This concession by Tasmania may not last if the matter is not resolved quickly. Yet several weeks may elapse before the waiting list for hearings in the high court is cleared.

At the core of the dispute is the power of the federal government to intervene in the affairs of state governments to uphold international treaties or conventions.

It is understood that the new federal regulation is an interim measure pending legislation to be introduced during the parliamentary sitting in May. Since the Australian Democrats holding the balance of power in the Senate have taken a strong anti-dam position, the measure is likely to have a smooth and speedy passage. On the face of it, however, if the present regulations are ruled invalid, legislation may fare no better because the same constitutional power is invoked in both cases. In that event, the federal government may have to resort to less direct means of achieving the desired goal, possibly by revoking the state's import and export licences or its authority to raise money overseas. Whatever the high court decision may be, Mr Gray has agreed to abide by it.
Vimala Sarma
Romanian emigrants Ceaucescu's

\section{claw-back}

ROMANIA's new emigration law, which demands that all citizens wishing to leave the country permanently must first repay the cost of their education, is an "internal matter" which does not contravene the Helsinki Final Act, according to President Nicolae Ceaucescu.

The law, which was abruptly introduced last November (as a decree of the Council of State) has evoked sharp criticism abroad, particularly in West Germany and Israel - virtually all emigrants from Romania during the past few years have been ethnic Germans or Jews - and in the United States, where the State Department has said that it stands in the way of the renewal of Romania's "most favoured nation" status, due to expire in June.

During a visit to Austria last month, President Ceaucescu told Alexander Wachsmuth, the Vienna correspondent of the West German news agency DPA, that the new regulations were simply a corollary of the existing Education Act of 1978, which obliges all graduates to work for a number of years in jobs assigned to them or otherwise to repay the cost of their tuition. Ceaucescu said that he personally knew very few young people who were reluctant to take up the jobs assigned to them so that there were very few instances of fees having to be repaid. He has also said that the decree is not discriminatory in that it applies equally to those of German and Jewish origin.

In addition to the threatened loss of "most favoured nation" status, foreign criticism of the law could impede President Ceaucescu's endeavours to act as mediator in the Lebanese war. As he told the Kuwait paper As-Siyasah, Romania "lives in the vicinity of the Middle East" and hence is directly concerned that peace should be established as soon as possible. But Israeli officials say that under present regulations, the "reunification of families" urged by the Helsinki Final Act can take place only if relatives abroad pay the education bills which, for a doctor of science, can exceed $\$ 40,000$.

In several respects the President's explanations seem somewhat ingenuous. The 1978 Education Act does indeed impose on school-leavers and students the duty to take up the posts to which they are assigned (Article 148/i) but education is guaranteed to be "free of charge, without payment of fees" (Article 126/a) and nothing is said about repayment of fees if a graduate does not go to the assigned job.

But if the new rules merely restate for intending emigrants the existing obligations on graduates, it is difficult to understand why there is not a sliding scale of rebates according to how many years the emigrant has worked in Romania. 